\title{
Collaborative Problem Solving Methods towards Critical Thinking
}

\author{
Khoo Yin Yin \\ Faculty of Management and Economics \\ Sultan Idris Education University \\ 35900 Tanjung Malim
}

Tel: 016-495-6578

\author{
Abdul Ghani Kanesan Abdullah \\ Associate Prof, School Educational Studies Universiti Sains-Malaysia \\ Tel: 60-4653-3428 E-mail: agk@usm.my
}

Naser Jamil Alazidiyeen

School Educational Studies Universiti Sains-Malaysia

Tel: 60-124-989-384Ｅ-mail: naser_jamel@yahoo.com

Received: January 4, 2011 Accepted: February 12, 2011 doi:10.5539/ies.v4n2p58

\begin{abstract}
This research attempts to examine the collaborative problem solving methods towards critical thinking based on economy (AE) and non economy (TE) in the SPM level among students in the lower sixth form. The quasi experiment method that uses the modal of $3 \mathrm{X} 2$ factorial is applied. 294 lower sixth form students from ten schools are distributed randomly into 3 groups (KPMs1, KPMs2 and KKv). Two hypotheses have been tested. The ANOVA procedure was applied to detect whether there are significant differences in the mean score of critical thinking among these three groups. The research findings showed that students from the KPMs1 group obtained the highest mean score in critical thinking. Likewise, students based on economy in the KPMs1 group showed the highest mean score in the Cornell Post-Test (Critical Thinking). The implications of the finding are discussed.
\end{abstract}

Keywords: Collaborative Problem Solving Methods, Critical Thinking, Economy Based, Non Economy Based

\section{Introduction}

The economic subject is classified as an art subject in the upper secondary STPM level (Malaysian Higher School Certificate). The sixth form students constantly face difficulties in comprehending concepts that are abstract, the analysis of statistic's data and graph explanation (Yusoff \& Masri, 2006). Such situation reported in research by Johnston, James, Lye and McDonald (2000) also revealed that the economy is a hard subject for secondary students and also for universities in Melbourne, Australia. The concept of economy and mathematical elements such as graph and statistics are the main skills required in this subject. This condition is more obvious among lower sixth form students who have newly taken this subject as they face difficulties in understanding concepts especially those who lack basics of economy during their SPM level. Researchers such as Johnston et al. (2000) conducted a study concerning the learning of economic and suggest that teachers should conduct better teaching in economics especially to students who have recently taken this subject in order to develop critical thinking besides encouraging them to contribute ideas while in the learning process.

The "chalk and talk" method is the main teaching method used by teachers as this overcomes the problem of an overwhelming number of students in a single class or enabling to finish the syllabus (Becker \& Watts, 2001). This method is considered a one-way teaching where students' involvement in learning is limited and passive. Alexander and McDougall (2001) suggested that an active learning situation such as the collaborative learning should be applied to overcome this one-way teaching. The situations in secondary schools in Malaysia, for example, students came to class without ample preparation and scarcely involve themselves in classroom discussions caused many to rely on teachers for answers (Yin \& Kassim, 2005). This situation does not contribute to the development of critical thinking. The economy subject teacher should conduct teaching and learning that involves active learning that enhances and 
develops students' critical thinking. Those teachers should also provide opportunities for students to conduct discussion sessions especially for the purpose of problem solving.

In the educational literature, there are few types of active learning, including the collaborative problem solving method, fact finding inquiries, case studies, project work and etc. The collaborative problem solving method is chosen as it involves a systematic group discussion that opens students' minds (Johnston, 1997; Johnston et al., 2000). This collaborative problem solving method is an active learning which is practical, profound and critical (Ramsden, 1992). According to Boud and Feletti (1991), the collaborative problem solving method can be defined as an approach that involves a few students coming together to discuss questions and problems given by the teachers whereby this stimulates students' self learning. The collaborative problem solving method (KPM) differs from the conventional learning method. It functions in a small group, usually consisting of four to six students in a group. According to Gokhale (1995), KPM is suitable to be conducted in learning the economy subject as this method is able to explore students' critical thinking. Critical thinking is emphasized in the sixth form curriculum as upper secondary students need skills in testing hypothesis, collecting data, making a conclusion and presenting a report. Nevertheless, students are scarcely exposed to activities that enhance and explore students' critical thinking. Students' involvement in collaborative problem solving is able to train them to practice qualities such as independence while improving their critical thinking skills in an upper secondary level (Atlas, 1995). The administration of the collaborative problem solving method (KPM) in classrooms will create a social network among group members. According to Ming (2000), a poorly conducted collaborative method will cause brighter students to dominate group activities, and thus shutting any opportunities for other group members to raise their views.

\section{Objectives}

The main objective of this research is to observe the effects of collaborative problem solving method with critical thinking based on systemic approach to problem solving (KPMs1), collaborative problem solving method with critical thinking but without a systemic approach (KPMs2), compared with conventional collaborative methods without treatment $(\mathrm{KKv})$ on the lower sixth form students for the purpose increasing their critical thinking skills.

\section{Methodology}

This research uses the quasi experiment research model (pre-test and post-test with controlled groups) to identify the effects of collaborative problem solving (experiment group) compared to the controlled group towards the increase of mean score in critical thinking. Researchers have improvised the three learning methods based on KPMs1, KPMs2 and $\mathrm{KKv}$. Every group is tested where students are divided into two groups (economy based and non economy based). In fact, 294 students were chosen from 10 schools. The research sample consists of students categorized according to SPM aggregates as the bench marker not exceeding eight units. In this study, the instrument is a set of Cornell CT Level X Test (CCT-X) that has been affirmed by the Cronbach Alpha value, .88 and the trustworthiness tested by four experts, which was found to be in a range between .87 and .91 (Ennis \& Millman, 1985). For the validation of the instrument, the back to back translation was applied on the Cornell CT Level X Test during the pilot testing.

\section{Findings Analysis}

This research takes into account the post-test results as students' pre-test results showed an interaction effect with the significant values. The findings revealed that the pre-test does not fulfill the MANOVA homogenous assumptions.

\subsection{Test of Hypothesis 1}

There are not much significant differences in the critical thinking's mean score between students that are exposed to collaborative problem solving methods with critical thinking, based on the systemic approach to problem solving (KPMs1) and critical thinking without a systemic approach (KPMs2) compared to students exposed to conventional collaborative methods without treatment (KKv).

The differences in mean also can be observed in Table 1. The findings showed that the mean difference among the three groups has influenced the reliability variable (critical thinking). This suggests that students' critical thinking is determined by the experiment method and the means of control being applied. According to Table 1, the Cornell's post-test mean score that measures the highest critical thinking level is obtained by the KPMs1 group (mean $=44.219$, standard deviation $=12.158)$, followed by KPMs2 $($ mean $=40.304$, standard deviation $=14.469)$ and $\mathrm{KKV}(\mathrm{mean}=$ 36.466 , standard deviation $=11.526$ ). Next, the Two Way ANOVA analysis is conducted. The ANOVA calculation results in Table 2 showed a significant effect towards the reliability variable (critical thinking). Meanwhile, there are also relatively high relationships between the collaborative problem solving method with critical thinking mean score, because the Eta value half squared has a value of .060 , meaning a $6.0 \%$ from the variance contributed by the collaborative problem solving method.

Based on the analysis showed in Table 2, Ho's results are disregarded. Meanwhile, the advanced comparison in the Post Hoc mean comparison was also conducted and the findings are tabulated in Table 3. 


\subsection{Test of Hypothesis 2}

Hypothesis 2 stated that "there are no significant differences in the critical thinking mean score between groups of students exposed to the collaborative problem solving method with collaborative problem solving method with critical thinking based on systemic approach method (KPMs1) and critical thinking without a systemic approach method (KPMs2) compared to students' with conventional methods without treatment (KKv) according to the of economy subject uptake on the SPM level". In order to test this hypothesis, two steps of analysis were taken under consideration. Firstly, we analyzed the mean, standard deviation and reliability, and second we used ANOVA test.

According to Table 4, the students in KPMs1 group recorded the highest mean score in the Cornell critical thinking post-test $($ mean $=48.370$, standard deviation $=10.408)$ at the $\mathrm{AE}$ level compared to KPMs2 students $($ mean $=42.235$, standard deviation $=12.468)$ and $\mathrm{KKv}($ mean $=36.417$, standard deviation $=8.402)$. The students in KPMs1 group at the TE level also recorded the highest mean, with a value of 42.931 in the Cornell post-test and a standard deviation of 12.425 , followed by KPMs2 $($ mean $=39.867$, standard deviation $=14.926)$ and $\mathrm{KKv}$ (mean=36.484, standard deviation $=12.557$ ).

Meanwhile, the researchers conducted further analysis to ensure the significant differences on each level. Table 5 showed an ANOVA analysis result for reliability variable which is critical thinking. Comparison is carried out between the three groups, KPMs1, KPMs2 and KKv in two stages.

The ANOVA findings showed a significant difference between AE level $\left(\mathrm{F}_{(2,65)}=8.534, p<.05\right)$ and $\mathrm{TE}\left(\mathrm{F}_{(2,223)}=\right.$ $4.320, p<.05)$ at the level of critical thinking mean score. The results denote that the problem solving methods influence the students' critical thinking mean score at the AE and TE level. The high relationship between collaborative problem solving method with the critical thinking mean score at the AE level, as Eta half squared $=.208$, indicating that $20.8 \%$ from the variance is contributed by the collaborative problem solving method. Nevertheless, the relatively low relationship at the TE level is due to the half squared Eta value $=.037$, denoting only $3.7 \%$ from the variance is contributed by the collaborative problem solving method. Based on the analysis from Table 5, Ho's result is again disregarded. Meanwhile, the further analysis of the Post Hoc mean comparison is also conducted and the findings are found in Table 6 .

\section{Discussion}

Critical thinking is a method of thinking that eases the process of providing opinions, making conclusions or wise choices. The research findings revealed the rejection of hypothesis 1 is caused by the significant critical thinking mean score differences between the KPMs1, KPMs2 and KKv methods. Students exposed to KPMs1 (mean $=44.22)$ successful recorded the highest mean score in Cornell's post-test compared to KPMs2 (mean $=40.30)$ and KKv (mean $=36.47$ ). This occurs similarly to hypothesis 2 , being disregarded as there are significant differences in students' critical thinking mean score, especially those who are exposed to KKv, based on students' uptake of basic economy paper in SPM. The Cornell post-test achievement is higher for the AE groups than the TE groups. Critical thinking is a method of thinking used to examine, appraise and revise previous or former knowledge to solve problems (Stratton, 2003). Nevertheless, the KPMs activities is able to develop critical thinking through discussions, idea classifications, evaluating ideas of other people, solving problems and producing ideas cooperately (Mills, 1994). Yet, quantitative findings do not show differences in elevating critical thinking.

In this research, the students in the KPMs group are designated to support each other and to prioritize a group's genuine character. This situation encourages students who are based on economy (AE) to assist students who are not based on economy (TE). Vygotsky (1997) stated that collaborative learning is able to solve problems raised while identifying one's weakness. In other words, the TE students are able to distinguish own weaknesses while carrying out discussions. In this research, students will be able to understand the demands and proposals in a clearer manner through mind maps. When students discuss using mind maps, they are able to grasp a wholesome picture besides have ease to produce ideas as mind maps are very stimulating. Students' cognitive changes can only be proved in quantitative findings. Yet, these findings do not support statements by Basadur (2002) and Canas et al. (2005) who suggested that problem solving activities can be carried out with mind mapping activities to assist students to think critically, to identify problems and to understand concepts in an extensive manner.

\section{Conclusion}

The success in conducting a learning method is dependent on teachers' and students' effort. If one of the parties chooses to abate one's role, for example, teachers do not give appropriate guidance to students or students are not ready to participate in a class, therefore even the best method does not appeal and produce outcome. Nevertheless, the success of KPMs also depends on students' ability to solve problems collaboratively and assist weaker members in achieving their goals. Therefore, KPMs is able to train students to build team spirit through depending on each other and interacting in discussions. The KPMs learning is very beneficial to students in developing students' character and individuality. Besides, researchers also hope that further studies can be conducted to produce a continuity to implicate 
the collaborative learning theory. Yet, the KPMs1 and KPMs2 method according to the Socio-Cultural Theory that leads to proximal development zone (Vygotsky, 1997) and Adult Learning Theory (Knowles, Holton \& Swanson, 1998) aims to develop a practical method in transforming teacher-centered learning methods to student-centered learning methods. Teachers are encouraged to use collaborative methods such as KPMs1 and KPMs2 in teaching economy subject to enable the achievement of teaching and learning objectives. The administration of KPMs1 and KPMs2 enable students to be trained and equipped in facing global economic competition.

\section{References}

Alexander, R. J., \& McDougall, R. S. (2001). Collaborative problem solving in student learning. University of Otago. Atlas, D. (1995). Critical thinking as problem solving. USA: Department of Education, Montana State University-Bozeman.

Basadur, M. (2002). Reducing complexity in concetual thinking using challenge mapping.[Online] Available: http://www.isce.edu/site/Basadur.pdf (September 1, 2009)

Becker, W., \& Watts, M. (2001). Teaching Methods in U.S. Undergraduate economics courses. Journal of Economic Education, 32(3), 269-80

Boud, D., \& Feletti, G. (1991). The challenge of problem based learning. London: Kogan Page.

Canas, A. J., Carff, R., Hill, G., Carvalho, M., \& Arguedas, M. (2005). Concept maps: Integrating knowledge and information visualization. In Tergan \& Keller, T.(Eds.), Knowledge \& Information Visualzation: Searching for Synergies. Heidelberg: Springer-Verlag. LNCS 3426, pp. 208-227

Ennis, R. H., \& Millman, J. (1985). Cornell Critical Thinking Test-Level XR., Pacific Grove, CA: Midwest Publication.

Gokhale, A. A. (1995). Collaborative learning enhances critical thinking. [Online] Available: http://bpkpenabur.or.id/paper- surabaya.htm(February 25, 2010)

Johnston, C. G., James, R.H., Lye, J. N., \& McDonald, I. M. (2000). An evaluation of collaboration problem solving for learning economics. Journal of Economic Education, 13-29

Johnston, C.G. (1997). Collaborative learning of economics in a peer tutoring context at the university of Melbourne. Australian Economic Papers O (Special Edition), 56-68

Knowles, M. S., Holton III, E.F., \& Swanson, R.A. (1998). The adult learner. Texas: Gulf Publishing Company.

Mills, C. (1994). Thinking through primary practice. Routledge.

Ming, C. M. (2000). Effects of status on solutions leadership and valuations during group problem solving. Journal of Sociology of Education, 73, 175-195

Ramsden, P. (1992). Learning to teach in higher education. Routledge, London,UK.

Stratton, J. (1999). Critical thinking for college students. England: Rowman \& Littlefield Publisher.

Vygotsky, L. S. (1997). The collected works of L.S. Vygotsky. In R.W. Riceber \& A.S. Carton (Ed.), Translated by N. Meanick. New York: Plenum.

Yin, K. Y., \& Kassim, Z. (2005). Pembelajaran Penyelesaian Masalah Secara Kaedah Kolaboratif dengan Pemikiran Kritis dan Kreatif di Kalangan Pelajar-pelajar Tingkatan Enam. Prosiding Seminar Pendidikan JPPG 2005. Shangri-La Inn, 28-30 Ogos, 2005.

Yusoff, M., \& Masri, Z. (2006). Penggunaan Teknik Lampu Trafik dalam Menentukan Aliran Keseimbangan Pendapatan Negara 2 Sektor bagi Meningkatkan Kemahiran Pelajar Tingkatan 6 Atas Ekonomi. Perak: SMK Dato Zulkifi Muhammad, Slim River, Perak.

Table 1. Mean, Standard Deviation and Standard Rectification for Independent Variables

\begin{tabular}{lllll}
\hline Dependent Variable & & KPMs1 & KPMs2 & KKv \\
& & $\mathrm{N}=114$ & $\mathrm{~N}=92$ & $\mathrm{~N}=88$ \\
\hline Critical Thinking & Mean & 44.219 & 40.304 & 36.466 \\
& Standard Deviation & 12.159 & 14.469 & 11.526 \\
& Standard Error & 1.194 & 1.329 & 1.359 \\
\hline
\end{tabular}


Table 2. Summary of ANOVA Analysis for Critical Thinking

\begin{tabular}{lll}
\hline DV & Univariate $\mathrm{F}$ & $p$ Value \\
\hline Critical Thinking & $9.237^{* *}$ & .000 \\
& $\mathrm{df}=2,291$ & \\
& Eta half Squared $=.060$ & \\
\hline
\end{tabular}

**sign. at $p<.01$

Table 3. Summary for Post Hoc Pairwise Comparison between Groups

\begin{tabular}{lll}
\hline Group Comparison & Univariate $\mathrm{F}$ & $p$ Value \\
\hline KPMs1 vs. KPMs2 & $6.135^{*}$ & .029 \\
KPMs1 vs KKv & $11.954^{* *}$ & .000 \\
KPMs2 vs KKv & $5.818^{*}$ & .044 \\
\hline
\end{tabular}

**Sign. at $\mathrm{p}<.01 ; *$ sign. at $\mathrm{p}<.05$

Table 4. Mean, Standard Deviation for Reliability Variable

\begin{tabular}{|c|c|c|c|c|c|}
\hline Level/Group & Dependent Variable & Group & $\mathrm{N}$ & Mean & $\mathrm{SD}$ \\
\hline \multirow{2}{*}{$\begin{array}{l}\text { Group } \\
\text { Basic } \\
\text { (AE) }\end{array}$} & \multirow[t]{3}{*}{ Critical Thinking } & KPMs1 & 27 & 48.370 & 10.408 \\
\hline & & KPMs2 & 17 & 42.235 & 12.468 \\
\hline & & $\mathrm{KKv}$ & 24 & 36.417 & 8.402 \\
\hline \multirow{3}{*}{$\begin{array}{l}\text { Group without } \\
\text { having } \\
\text { Economy (TE) }\end{array}$} & \multirow[t]{3}{*}{ Critical Thinking } & KPMs1 & 87 & 42.931 & 12.425 \\
\hline & & KPMs2 & 75 & 39.867 & 14.926 \\
\hline & & $\mathrm{KKv}$ & 64 & 36.484 & 12.557 \\
\hline
\end{tabular}

Table 5. Summary for ANOVA Analysis for Critical Thinking

\begin{tabular}{|c|c|c|c|}
\hline Dependent Variable & Level & Univariate $F$ value & $p$ value \\
\hline \multirow{6}{*}{ Critical Thinking } & $\begin{array}{l}\text { AE (Group having Basic } \\
\text { Economy ) }\end{array}$ & $\mathrm{F}=8.534 * *$ & .001 \\
\hline & & $\mathrm{df}=2,65$ & \multirow{5}{*}{.014} \\
\hline & \multirow{4}{*}{$\begin{array}{l}\text { TE Group without having basic } \\
\text { Economy (AE) }\end{array}$} & Eta half squared $=.208$ & \\
\hline & & $\mathrm{F}=4.320^{*}$ & \\
\hline & & $\mathrm{df}=2,223$ & \\
\hline & & Eta half squared $=.037$ & \\
\hline
\end{tabular}

**Sign. at $p<.01 ; *$ sign. at $\mathrm{p}<.05$

Table 6. Summary for Post Hoc Pairwise Comparison between Groups

\begin{tabular}{lll}
\hline Group Comparison & Univariate $\mathrm{F}$ & $p$ Value \\
\hline KPMs1vs. KPMs2 & $3.915^{*}$ & .029 \\
KPMs1 vs KKv & $7.753^{* *}$ & .000 \\
KPMs2 vs KKv & $3.838^{*}$ & .044 \\
\hline
\end{tabular}

